\title{
ASPECT IN THE IMPERATIVE ACROSS SLAVIC - A CORPUS DRIVEN PILOT STUDY
}

\author{
RUPRECHT VON WALDENFELS \\ Universität Bern
}

ABS TRACT

The paper introduces a quantitative approach to using a parallel corpus for the investigation of category variation across Slavic. As a pilot case study, it presents the corpus-driven study of aspect in the imperative, drawing on 13 versions of Bulgakov's Master i Margarita in 11 Slavic languages as included in the ParaSol corpus (von Waldenfels 2006). Taking departure from imperative contexts in the Russian original, it is shown that differences in aspect use follow an areal pattern. The results are largely consistent with theories such as forwarded by Barentsen $(1998,2008)$ and Dickey $(2000)$ that emphasize the existence of two focal groups of aspect use in the East and the West and confirm the results of a questionnaire-based study reported in Benacchio (2010).

\section{[1] INTRODUCTION}

\section{[1.1] Aspect variation across Slavic}

In recent years a comparative perspective on Slavic aspect has gained increasing prominence (Dickey 2000; Barentsen 1998; Петрухина 2000; Barentsen 2008). Among others, Dickey (2000) argues for an east-west split with the East Slavic languages and Bulgarian in one, and Czech, Slovak and Slovene in a second group. Differences in aspect use are said to be based on different prototypical meanings of the category in these two groups; Polish and BCS are considered transitional zones. In Dickey \& Kresin (2009) this analysis is argued to be also relevant for the use of aspect in negated past events, corroborating a prototype based theory of aspect in these languages.

The present paper puts aspects of these theories to a test in a restricted environment, focusing on verbal aspect in the morphological imperative. By examining aspect use in comparable texts in all major Slavic languages in a quantitative way and relating them to another, the present study confirms, first, the general finding of an areal distribution of aspect use across Slavic, and, second, the specific East-West contrast posited by Dickey (2000). 


\section{[1.2] Aspect in the imperative}

For the present pilot study, the non-negated imperative was chosen as an at the same time interesting and largely unproblematic environment. It is largely unproblematic because, first, all slavic languages possess such a morphological category; second, because the use of this category is rather consistent across Slavic; third, because it is used rather independently of other constructions, i.e., it is not normally embedded into other structures; third, it seems to be less subject to variation under translation than, say, events in an event chain. Furthermore, aspect use in this environment is not grammatically restricted in any of the languages involved. Imperatives are thus both comparably easy to extract from a corpus and comparably easy to compare across Slavic languages.

Aspect use in the imperative has been a recurrent topic in the aspectological literature on Russian, where a set of pragmatic functions of the aspectual opposition is noted. Wiemer (2008) nicely summarizes the most important distinction:

The bottom line of the matter [is] that imperfective verbs are used in the non-negated imperative if the speaker supposes that the [appropriateness of the] action in question is self-evident, e.g. because it belongs to the relevant script or because it has already been introduced; perfective verbs are used if the speaker does not suppose this and the situation in question is therefore considered new or unexpected (Wiemer 2008, my translation ${ }^{1}$ )

In a series of papers and culminating in a book on the subject, Benacchio (2004, 2005,2010 ) has enlarged the scope to the other Slavic languages, taking as point of departure those context types found relevant in the literature on Russian. Her work is based on questionnaire data and informant work and concerned with aspect in the imperative in Russian, Ukrainian, Belarusian, Bulgarian, Macedonian, Bosnian/Croatian/Serbian, Slovene, Upper Sorbian, Lower Sorbian, Czech, Slovak and Polish, i.e., almost all Slavic literary languages. Moreover, she also takes Modern Greek into perspective, thereby broadening the scope beyond Slavic. As concerns areal grouping, her results are broadly compatible with those of Dickey's: she finds aspect use in the East Slavic languages to be strongly alike and clearly divergent from its use in the Western languages, with intermediate types for Bulgarian and Polish.

According to Benacchio's findings, the use of the imperfective in contexts where there is an opposition in the East involves pragmatic effects that become

[1] Als Quintessenz darf man ansehen, daß im unnegierten Imperativ ipf. Verben dann gewählt werden, wenn der Sprecher voraussetzt, daß die betreffende Handlung sich bereits von selbst versteht, z.B. weil sie zum Skriptwissen gehört oder weil die Handlung vorher schon einmal erwähnt worden ist, pf. Verben hingegen dann, wenn der Sprecher meint, dies nicht voraussetzen zu können und die jeweilige Situation in diesem Sinne neu bzw. unerwartet ist. Wiemer (2008) 
less felicitous as one moves to the west, resulting in ungrammaticality of the imperfective in Czech, Slovak, Slovene and Lower and Upper Sorbian. The meanings involved relate to politeness categories that are said to differ across the areal; they range from positive politeness strategies and the expression of familiarity more to the East and a sense of urgency and outright imposition as one moves towards the Western Group.

\section{[1.3] A corpus driven approach}

Rather than taking departure from aspectual functions and specific contexts in any of the languages, the approach draws on patterns of aspect use in all imperative forms found in a set of texts; it is in this sense strictly corpus driven. The analysis is based on multiple translations of Mikhail Bulgakov's Master i Margari$t a$ as included in the ParaSol parallel corpus (von Waldenfels 2006). Translations into all major literary Slavic languages (except the two Sorbian languages) are included in ParaSol; in Polish and Serbian, two translations are available ${ }^{2}$.

It is important to keep in mind that the study is based on the language of a series of specific texts, the degree of representativity of which is open to question. Therefore I speak of doculects rather than of languages where appropriate.

\section{[2] DATA AND ANNOTATION}

The category of imperative is quite similar across Slavic, but there is some variation nonetheless. The following constructions were taken into account: the synthetic imperative of the 2. Person singular and plural that is present in all Slavic (e.g. Bulgarian daŭ / daŭme 'give!'); the synthetic imperative of the 1. person plural, of varying status and form across Slavic (e.g., Polish stuchajmy 'let's listen!'); constructions considered grammaticalized analytical imperative forms in Hansen (2004): the Polish analytical polite imperative formed with prosze (prosze powiedziéc '(please) say') and the 1 . person plural imperative formed with даваŭ/me in Russian (e.g., давайте петь (ipf) / давайте споем (pf) 'let's sing!'; cf. Храковский \& Володин 1986, 121f.) as well as cognate constructions in the other East Slavic languages. The rare case of imperatives in imperative function (e.g., Russian вставать! 'Get up!') was also taken into account. For the purposes of this study, all these constructions were considered equivalent in respect to aspect usage (even though this may be an oversimplification). Other means of expressing the speech acts in question, e.g., modal verbs, were not taken into account. Pragmatic markers such as npocmume 'excuse me', npoщ̧aŭ 'farewell', as well as imperative forms in non-imperative function (such as the narrative imperative) were likewise discarded.

[2] The same abbreviations as in the ParaSol corpus are used in this paper: RU Russian, BY Belarusian, UK Ukrainian, PL Polish, SK Slovak, CZ Czech, SL Slovene, HR Croatian, SR Serbian, MK Macedonian, BG Bulgarian. 
Having thus delimited the scope of forms taken into account, the data basis for the investigation is collected in three steps: Query and filtering, base annotation and full annotation. These procedures will be described in the rest of this section; I will then turn to data aggregation and visualization before reaching conclusions.

\section{Query and filtering}

In a first step, all word forms tagged as morphological imperatives in the Russian original were extracted from ParaSol together with their aligned segments. The resulting XML file was then transformed using XSLT into a data base format; morphological and other information from the aligned segments was used to automatically determine candidates for word forms equivalent to the Russian one. The data were then loaded into MS Access where they were examined on a individual basis and either annotated or discarded (if irrelevant according to the above list or due to tagging errors).

\section{Base annotation}

For the Russian, Slovene, Czech, Slovak and two Polish translations, ParaSol supplies morphological tags ${ }^{3}$, considerably easing the task of assigning aspect values to each instance. On the basis of this annotation, each context was assigned to one of three types, depending on the distribution of aspect values across texts: consistently perfective, consistently imperfective, or with variation.

Of 362 relevant cases, 194 (54\%) were classified as CONSISTENTLY PERFECTIVE. This typically involved imperatives relating to telic actions that were taken into perspective as a whole and uttered without much context support. As an example, consider (1). The context is as follows: Jesus is brought before Pilate to answer to the allegations brought up against him. During the conversation, Jesus calls Pilate 'a good man', whereupon Pilate has Jesus punished for the transgression. He does this by issuing the following command to one of his soldiers. We are thus dealing with the causation of a telic event that is not expected by virtue of script knowledge or on other grounds and expressed in perfective aspect in the 6 base doculects:

(1) Выведите $e_{f}$ его отсюда на минуту, объясните ему, как надо разговаривать со мной.

Wyprowadź $_{p f}$ go stąd na chwilę i wyjaśnij mu, jak należy się do mnie zwracać.

Wyprowadzić $_{p f}$ go i wytłumaczyć, jak należy ze mną rozmawiać. $\quad$ PL Odved'te $_{p f}$ ho na chvílu a vysvetlite mu, ako sa má so mnou rozprávat. SK Odved $_{p f}$ ho a vysvětli mu, jak se mnou má mluvit.

Odpeljite $_{p f}$ ga za trenutek od tod in mu pojasnite, kako je treba govoriti z

[3] Note that morphosyntactic annotation for Bulgarian has since been added. 
menoj.

'Take him outside for a moment, explain to him how I ought to be spoken to.'

A much lesser number, 49 cases (14\%) were classified as consistently imperfective. Typically, this involved the causation of atelic situations, often also their continuation. An example is given in (2):

(2) И слушай меня: если с этой минуты ты произнесешь хотя бы одно слово, заговоришь с кем-нибудь, берегись ${ }_{i p f}$ меня! RU I zapamiętaj sobie, że jeśli powiesz od tej chwili choćby jedno słowo, jeśli będziesz z kimkolwiek rozmawiał - to strzeż sięipf mnie! A teraz słuchaj: jeśli od tej chwili wypowiesz choć jedno słowo, zaczniesz z kimś rozmawiać - strzeż $\dot{z i p f}_{\text {się mnie! }}$ ...ak od tejto chvíle prerečieš čo len slovo, ak sa s niekým budeš zhovárat', maj sa predo mnou na pozore! A ted' dobře poslouchej: jestli od této chvíle hlesneš, varuj ${ }_{i p f}$ se mě, to ti povídám!

In poslušaj me: če od tega trenutka naprej izrečeš le besedo, spregovoriš s komer si bodi, potem se me pazi $\mathbf{i}_{i p f}$ ! 'if from this moment on you say even one word, if you speak to anyone at all, beware of me!'

Cases that do not exhibit variation in the use of either the imperfective, such as (1), or perfective aspect, such as (2), arguably belong to an invariable core of the category in Slavic. The contexts assigned to either category were not further investigated.

\section{Full annotation}

In 118 (33\%) of 362 cases base annotation revealed differences in aspect use across the initial six doculects and were assigned to the VARIATION group. For these contexts the analysis was expanded to include all translations. The relevant imperative forms were annotated and their aspectual value was determined using standard dictionaries. Note that annotation was conservative: In cases of doubt or conflicting classification in standard dictionaries, verb forms were coded as biaspectual.

In the following attestation, for example, there is variation in the first six texts: 'repeat it a third time' is expressed with a perfective imperative in all but the Czech version, where an imperfective form was used. Therefore, analysis was expanded to the full set of available translations:

(3) Первосвященник, повтори ${ }_{p f}$ в третий раз. 
Powtórz $_{p f}$ to po raz trzeci, arcykapłanie. $\quad$ PL

Vel'kňaz, zopakuj ${ }_{p f}$ to tretí raz. $\quad$ SK

Opakuj $_{i p f}$ to potřetí, velekněže. $\quad C Z$

Veliki duhoven, ponovi $_{p f}$ mi to še tretjič. $\quad$ SL

Першасвятар, паўтары ${ }_{f f}$ трэці раз! BY

Первосвященику, повтори $f_{f}$ втретє. UK

Първосвещенико, потвърди ${ }_{p f}$ го и трети път. BG

Првосвештенику, повтори ${ }_{p}$ го тоа и по трет пат. MK

Prvosvešteniče, ponovi $i_{p f}$ i treći put. $\quad$ SR

Prvo svešteniče, ponovi $i_{p f}$ i treći put. SR

Prvosvećeniče, ponovi $i_{f}$ treći put. HR

'Repeat it a third time, High Priest.'

In this case, variation does not seem to follow a wider pattern: only the Czech translation uses an imperfective form ${ }^{4}$. In other cases, expansion of focus to all translations in fact reveals more wide-spread variation. In (4) Czech and Slovene use perfective aspect, while Russian and two Polish translations show imperfective aspect:

(4) [...] ты когда-либо говорил что-нибудь о великом кесаре?

Отвечай ${ }_{i p f}$ ! RU

Odpowiadaj $_{i p f} ! \quad$ PL

Odpowiadaj $_{\text {ipf }}$ ! $\quad$ PL

Odpovedz $_{p f}$ ! $\quad$ SK

Odpověz $_{p f}$ ! $\quad$ CZ

Odgovori $_{p f}$ ! SL

'[...] did you ever say anything about the great Caesar? Answer!'

The use of the imperfective in Russian is well accounted for here: the question in the first part 'did you ever say anything about the great Caesar?' provides ample grounds for the explicit 'Answer!' to be an expected command with clear context support.

Widening the perspective to all available translations, we see that only the far West - Czech, Slovak, Slovenian and Croatian - uses the perfective where the other language versions have imperfective aspect:

(4) Відповідай ${ }_{i p f}$ ! UK

Адказвай ${ }_{i p f}$ ! BY

Отговаряй ${ }_{i p f}$ ! BG

Одговарај ipf $_{\text {! }}$ MK

[4] I am obliged to Saša Rosen and Radovan Garabík for pointing out that in this case, both aspects are admissible in both Czech and Slovak. 
Odgovaraj $_{i p f} !$

SR

Odgovaraj $_{i p f}$ !

SR

Odgovori $_{p f}$ !

HR

This example thus fits in nicely with the general picture of Dickey's East-West split and with Benacchio's result that in contexts where in the Eastern languages there is a pragmatic opposition resulting in the use of the imperfective, the Western Group prefers the perfective.

But to what extent is this particular context representative for the general picture and to what extent is this merely anecdotal evidence? In order to obtain a more comprehensive perspective on the variation in the data, in the next step, they are transformed to a distance matrix and visualized using specialized software.

[3] Aggregation: COMPUting DoCULECT Distances

$\begin{array}{lllllllllllllllllll}\text { Russian } & \mathrm{p} & \mathrm{p} & \mathrm{i} & \mathrm{i} & \mathrm{i} & \mathrm{p} & \mathrm{p} & \mathrm{p} & \mathrm{p} & \mathrm{i} & \mathrm{i} & \mathrm{i} & \mathrm{p} & \mathrm{i} & \mathrm{i} & \mathrm{i} & \mathrm{i} \\ \text { Belarusian } & \mathrm{i} & \mathrm{i} & \mathrm{i} & \mathrm{i} & \mathrm{i} & \mathrm{p} & \mathrm{p} & \mathrm{p} & \mathrm{p} & \mathrm{i} & \mathrm{i} & \mathrm{i} & \mathrm{p} & \mathrm{i} & \mathrm{i} & \mathrm{i} & \mathrm{i} \\ \text { Ukrainian } & \mathrm{i} & \mathrm{p} & - & \mathrm{i} & \mathrm{i} & \mathrm{p} & \mathrm{p} & - & \mathrm{p} & \mathrm{i} & \mathrm{i} & \mathrm{i} & \mathrm{p} & \mathrm{i} & \mathrm{i} & \mathrm{i} & \mathrm{i} \\ \text { Bulgarian } & \mathrm{i} & \mathrm{p} & \mathrm{i} & - & \mathrm{i} & \mathrm{i} & \mathrm{p} & \mathrm{p} & \mathrm{p} & \mathrm{i} & - & \mathrm{p} & \mathrm{p} & \mathrm{p} & \mathrm{p} & \mathrm{p} & - \\ \text { Macedonian } & \mathrm{p} & \mathrm{p} & \mathrm{i} & \mathrm{p} & \mathrm{i} & \mathrm{p} & \mathrm{p} & \mathrm{p} & - & \mathrm{p} & \mathrm{i} & \mathrm{i} & \mathrm{p} & \mathrm{p} & \mathrm{p} & \mathrm{p} & \mathrm{i} \\ \text { Serbian } & \mathrm{i} & \mathrm{p} & \mathrm{i} & - & \mathrm{i} & \mathrm{p} & \mathrm{i} & \mathrm{p} & - & \mathrm{p} & \mathrm{i} & \mathrm{i} & \mathrm{i} & \mathrm{p} & \mathrm{p} & \mathrm{p} & \mathrm{i} \\ \text { Serbian/2 } & - & \mathrm{p} & \mathrm{i} & \mathrm{p} & \mathrm{i} & \mathrm{p} & \mathrm{p} & \mathrm{p} & \mathrm{p} & \mathrm{i} & \mathrm{i} & \mathrm{i} & - & - & \mathrm{p} & \mathrm{p} & \mathrm{i} \\ \text { Croatian } & - & \mathrm{p} & \mathrm{i} & \mathrm{p} & \mathrm{i} & \mathrm{p} & \mathrm{p} & \mathrm{p} & \mathrm{p} & \mathrm{p} & \mathrm{i} & \mathrm{i} & \mathrm{i} & \mathrm{p} & \mathrm{p} & \mathrm{p} & \mathrm{i} \\ \text { Slovenian } & \mathrm{p} & \mathrm{p} & \mathrm{i} & \mathrm{p} & \mathrm{p} & \mathrm{p} & \mathrm{i} & \mathrm{i} & - & \mathrm{p} & \mathrm{p} & \mathrm{p} & \mathrm{i} & \mathrm{p} & \mathrm{p} & \mathrm{p} & - \\ \text { Czech } & \mathrm{i} & \mathrm{p} & - & \mathrm{i} & \mathrm{i} & \mathrm{i} & \mathrm{i} & \mathrm{p} & \mathrm{i} & \mathrm{p} & \mathrm{p} & \mathrm{p} & \mathrm{p} & \mathrm{p} & \mathrm{p} & \mathrm{p} & \mathrm{p} \\ \text { Slovak } & \mathrm{i} & - & - & - & \mathrm{p} & \mathrm{p} & \mathrm{i} & - & \mathrm{p} & \mathrm{i} & \mathrm{p} & \mathrm{i} & - & \mathrm{p} & \mathrm{p} & \mathrm{p} & \mathrm{p} \\ \text { Polish } & \mathrm{i} & \mathrm{i} & \mathrm{p} & - & \mathrm{i} & \mathrm{i} & \mathrm{p} & \mathrm{p} & \mathrm{p} & - & \mathrm{p} & \mathrm{i} & \mathrm{i} & \mathrm{i} & \mathrm{p} & \mathrm{p} & \mathrm{i} \\ \text { Polish/2 } & \mathrm{i} & \mathrm{i} & \mathrm{i} & - & \mathrm{i} & \mathrm{i} & \mathrm{p} & \mathrm{p} & \mathrm{p} & \mathrm{i} & \mathrm{p} & \mathrm{i} & \mathrm{p} & - & \mathrm{p} & \mathrm{p} & \mathrm{i}\end{array}$

TABLE 1: A small excerpt of the data matrix. Each row represents a text; each column one context. Each cell of the table contains $i$ if the imperative form in the relevant context and text is in imperfective aspect, $p$ if it is in perfective aspect and - in all remaining cases.

For the aggregation of doculect differences, only the fully annotated contexts, that is, those contexts where aspect use was neither consistently perfective nor consistently imperfective, are represented in a table.

An excerpt of this table is given in 1 . Each column represents a specific context. Doculects are represented as rows of values: either $p$, if the imperative form 


$\begin{array}{lllllllllll}\text { Russian } & \mathrm{p} & \mathrm{p} & \mathrm{p} & \mathrm{p} & \mathrm{i} & \mathrm{i} & \mathrm{i} & \mathrm{p} & \mathrm{i} & \mathrm{i} \\ \text { Polish } & \mathrm{i} & \mathrm{p} & \mathrm{p} & \mathrm{p} & - & \mathrm{p} & \mathrm{i} & \mathrm{i} & \mathrm{i} & \mathrm{p} \\ \text { Czech } & \mathrm{i} & \mathrm{i} & \mathrm{p} & \mathrm{i} & \mathrm{p} & \mathrm{p} & \mathrm{p} & \mathrm{p} & \mathrm{p} & \mathrm{p}\end{array}$

TABLE 2: Illustrating the computation of hamming distance between doculects. In the Russian-Polish pair, 4 of 9 contexts differ in aspect value, so distance $h=4 / 9=.444$; between Czech and Polish, 5 of 9 contexts differ, so $h=.555$. Between Czech and Russian, only 2 of 10 contexts coincide, so the distance is much higher at $h=.8$.

in the given context is perfective, $i$, if it is imperfective. In case the verb in question is biaspectual or if the relevant context does not contain an imperative, the cell is assigned -. The resulting full table represents the complete data to be analyzed.

In the next step, the data are used to compute the hamming distances between pairs of doculects ranging from 0 (if the two texts always use the same aspect in the same context) or 1 (if they never do).

This is done by dividing the number of contexts with the same aspect value in both doculects by the number of all contexts (counting only those contexts where an aspect value was assigned in both texts). Table 2 gives an example of this calculation based on a limited excerpt of the table.

Such a calculation is made for each pair of doculects, arriving at the distance matrix given in table 3. These distances reflect the overall similarity or dissimilarity of aspect use in imperatives across the doculects. However, such a set of distances is not easy to interpret. To this end, the data is visualized in the next step.

\section{[4] VisualizATION：NEIGHBORNET GRAPHS}

The data was visualized using SplitsTree (Huson \& Bryant 2006), a software package developed for the visualization of biological data. Figure 1 contains a NeighborNet graph, a graphical rendering of the data. This graph faithfully represents the distances contained in the distance matrix: shortest paths between the doculect nodes are proportional to distances in the matrix. Since this is the case for all distances, the graph also displays similarity in respect to other doculects. To see this, consider the two Polish translations. Not only are they adjacent, i.e., most similar to each other, they are also very similar in respect to the distances to the other doculects, as reflected in the overall position of the two and in the structure of the network. 
$\begin{array}{lllllllllllll}\text { RU } & \text { BY } & \text { UK } & \text { BG } & \text { MK } & \text { SR } & \text { SR2 } & \text { HR } & \text { SL } & \text { CZ } & \text { SK } & \text { PL } & \text { PL2 }\end{array}$

$\begin{array}{llllllllllllll}\text { RU } & 0 & .13 & .1 & .4 & .48 & .49 & .43 & .54 & .76 & .75 & .59 & .44 & .39\end{array}$

$\begin{array}{llllllllllllll}\text { BY } & .13 & 0 & .14 & .39 & .45 & .44 & .4 & .52 & .73 & .69 & .57 & .37 & .34\end{array}$

$\begin{array}{llllllllllllll}\text { UK } & .1 & .14 & 0 & .42 & .46 & .47 & .42 & .51 & .72 & .75 & .53 & .4 & .36\end{array}$

$\begin{array}{llllllllllllll}\text { BG } & .4 & .39 & .42 & 0 & .32 & .31 & .34 & .28 & .39 & .46 & .37 & .38 & .39\end{array}$

$\begin{array}{llllllllllllll}\text { MK } & .48 & .45 & .46 & .32 & 0 & .26 & .25 & .16 & .34 & .39 & .35 & .41 & .39\end{array}$

$\begin{array}{llllllllllllll}\text { SR } & .49 & .44 & .47 & .31 & .26 & 0 & .21 & .2 & .38 & .4 & .36 & .41 & .43\end{array}$

$\begin{array}{llllllllllllll}\text { SR } 2 & .43 & .4 & .42 & .34 & .25 & .21 & 0 & .19 & .48 & .43 & .34 & .39 & .36\end{array}$

$\begin{array}{llllllllllllll}\text { HR } & .54 & .52 & .51 & .28 & .16 & .2 & .19 & 0 & .24 & .4 & .3 & .44 & .43\end{array}$

$\begin{array}{llllllllllllll}\text { SL } & .76 & .73 & .72 & .39 & .34 & .38 & .48 & .24 & 0 & .38 & .33 & .6 & .61\end{array}$

$\begin{array}{llllllllllllll}\mathrm{CZ} & .75 & .69 & .75 & .46 & .39 & .4 & .43 & .4 & .38 & 0 & .28 & .56 & .56\end{array}$

$\begin{array}{llllllllllllll}\text { SK } & .59 & .57 & .53 & .37 & .35 & .36 & .34 & .3 & .33 & .28 & 0 & .44 & .56\end{array}$

$\begin{array}{llllllllllllll}\mathrm{PL} & .44 & .37 & .4 & .38 & .41 & .41 & .39 & .44 & .6 & .56 & .44 & 0 & .22\end{array}$

$\begin{array}{llllllllllllll}\text { PL2 } & .39 & .34 & .36 & .39 & .39 & .43 & .36 & .43 & .61 & .56 & .56 & .22 & 0\end{array}$

TABLE 3: Pairwise doculect distances. Abbreviations see footnote 2.

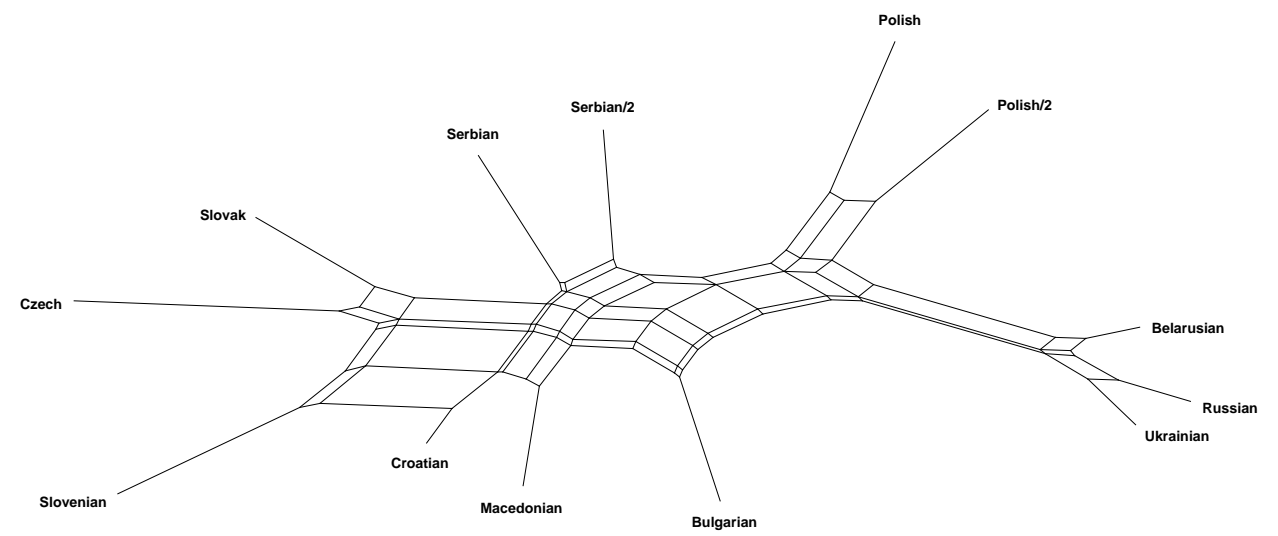

FIGURE 1: NeighborNet graph of aspect-based distances of 13 doculects. 


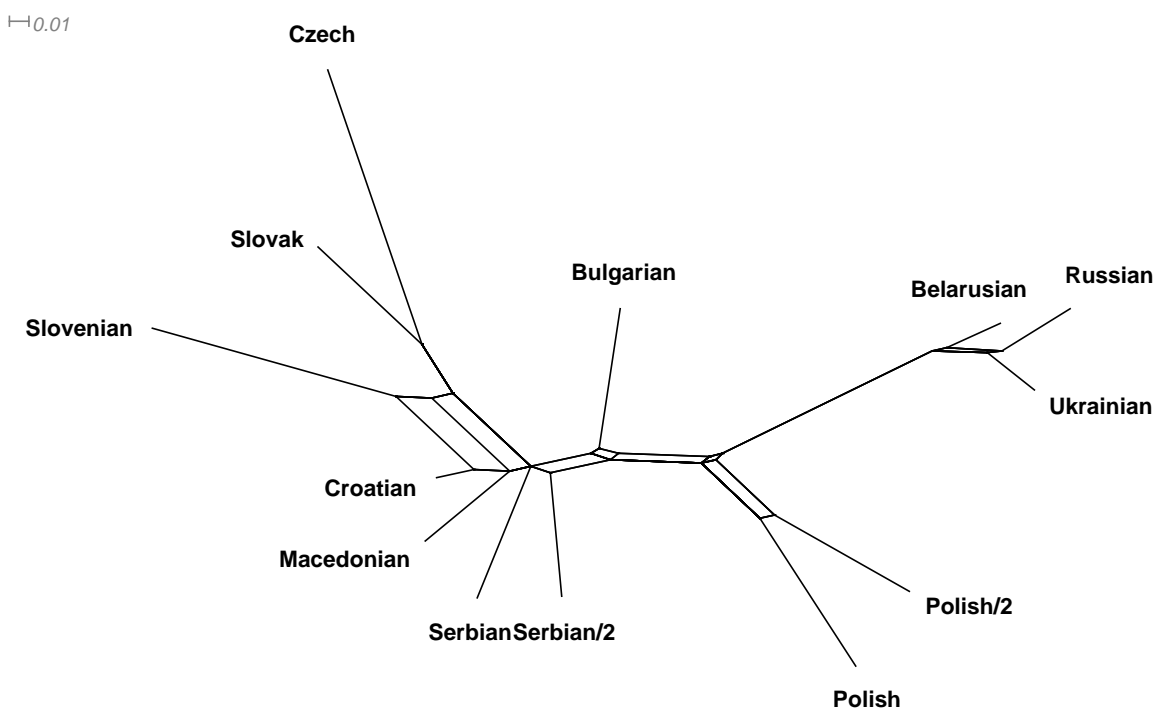

FIGURE 2: NeighborNet graph of aspect-based distances of 13 doculects after bootstrapping $(\mathrm{n}=1000) ; 95 \%$ confidence margin.

Other details such as the position of the nodes in the two-dimensional plane and the figure's orientation are arbitrary; the figure has been turned to align it to the geographic position of the Slavic languages as far as possible.

The graph reveals some expected, and some surprising details. First of all, we see that the three East Slavic versions as well as the two translations each into Serbian and Polish are most similar to each other; this is expected. Likewise, the Czech and Slovak texts are very similar and together with the Slovenian one form a group that is diametrically opposed to the Eastern Slavic texts. This confirms the relevance of two (rather than three or four) extreme groups in relation to the category of aspect posited in the literature: a Western group, consisting of Czech, Slovak and Slovenian, and an Eastern group, with the East Slavic languages at its core. Likewise compatible with this theory is the position of the other texts: The middle and East South Slavic versions as well as the Polish translations are situated between the two poles, with Bosnian/Serbian/Croatian and Bulgarian tending towards the Western, and Polish tending towards the Eastern group. However, we also see that the Macedonian translation is nearer to the Croatian than to the Bulgarian or to one of the Serbian texts; this is rather astonishing given the intermediate position of Macedonian between Bulgarian and Serbian in many respects.

But how significant are these results? In the end, the graph is built on quite heterogeneous data shaped by the vagaries of the translation process, a small and 
idiosyncratic corpus and a limited number of examples. To minimize the impact of individual chance configurations, a measure of confidence is needed. To this end, a bootstrapping function is available in SplitsTree. Bootstrapping is a validation technique that consists of repeatedly recalculating the distance matrices with a certain portion of the data withheld. In this way, many distance matrices on the basis of slightly different data are computed and then compared. Distances that do not fluctuate are then deemed more significant than distances that are found only in a small portion of the calculated matrices.

Figure 2 shows a NeighborNet graph computed on the basis of 1000 -fold bootstrapping and a confidence margin of $95 \%$. It is less detailed, containing only the information that is unlikely to be due to chance. This graph, again, confirms the close proximity of the Eastern Slavic original and translations, as well as the other groups that are expected as a base line: the Serbian and Polish alternate translations and the Czech and the Slovak text. Moreover, the differences between Croatian and Serbian have, as expected, diminished, as has the distance of Macedonian and Serbian. The graph now displays a central group of texts in former Yugoslav languages excluding Slovenian, with Croatian tending towards the Western Group. The Bulgarian text, in contrast, stands apart and nearer to the East Slavic versions than the other South Slavic languages. The Polish translations, finally, stand closest to the Eastern Group; this is in accordance with Benacchio's (2010) findings. Note that the fact that the Polish translations are nearer to the Russian text than Bulgarian is not expected in the light of Dickey's more general assessment of Bulgarian as a member of the Eastern aspectual group (which, however, does not explicitly address aspect use in the imperative).

\section{[5] CONCLUSIONS}

Results and outlook

The present study has presented an empirical, corpus driven approach towards the comparative analysis of aspect in in the imperative. It takes departure from a given corpus and explicit procedures. Its results are therefore in principle reproducible, and an important direction for further study is the validation and exploration of this method using other texts and categories.

The results attained are preliminary, but encouraging: in broad terms, the study supports the validity of a basic division of Slavic languages on the basis of aspectual functions in an Eastern and an Western group. However, its results also call into question the dichotomy of such a division: if there are so many intermediate positions, what does this entail for the qualitative analysis of the aspect category across Slavic? Are we really dealing with mixtures of two cognitive concepts underlying the Western and Eastern aspectual systems, or is there perhaps a much more varied picture of a multitude of micro-functions that still need to be 
explored? It stands to reason that a principled assessment of a panslavic parallel corpus such as ParaSol may have much to tell here.

The analysis of translations for contrastive studies usually involves a hypothesis of equivalence across language versions: we pretend to be dealing with the very same contexts in different languages. However, this hypothesis is quite untenable, and using translated texts for the study of grammatical categories is always a problematic enterprise: translated texts are different from originally produced texts both due to priming by the language of their original sources as well as by universals of translated texts (Mauranen 2008).

The present study shows that using multiple translations and many languages can serve to balance these effects: if translations into closely related varieties coincide in aspect use, this can be taken as an argument for the significance of these cases for tendencies that go beyond a specific variety. However, this, as well as other methodological issues pertinent to such an approach are left to be explored in further research.

\section{ACKNOWLEDGMENTS}

Thanks are due to audiences at the BeLing colloquium, at The Russian Verb conference in St.Petersburg and at Slavicorp in Warsaw as well as to the anonymous reviewer. I would like to thank Bernhard Wälchli for our valuable discussions of the method and data reported in this paper. All errors are, needless to say, mine.

\section{REF ERENCES}

Barentsen, Adrian. 1998. Признак «секвентая связь» и видовое противопоставление в русском языке. In М.Ю.Черткова (ed.), Типология вида: проблемы, поиски, решения, 43-58. Москва: Языки русской культуры.

Barentsen, Adrian. 2008. Выражение последовательности действий при повторяемости в прошлом в современных славянских языках [The expression of the sequentiality of repeated actions in the past in the modern Slavic languages]. In Dutch Contributions to the Fourteenth International Congress of Slavists, Ohrid: Linguistics, 1-36. Amsterdam - New York: Rodopi.

Benacchio, Rosanna. 2004. Глагольный вид в императиве в южнославянских языках. In Сокровенные мысли. Слово. Текст. Культура., 267-275. Москва.

Benacchio, Rosanna. 2005. Глагольный вид в императиве в чешском и словацком языках. In Язык. Личность. Текст. Сборник статей к 70-летию T.м. Николаевой, 191-200. Москва.

Benacchio, Rosanna. 2010. Вид и категория вежливости в славянском императиве. Сравнительный анализ. München, Berlin: Kubon und Sagner. 
Dickey, S.M. \& S.C. Kresin. 2009. Verbal aspect and negation in Russian and Czech. Russian Linguistics 33(2). 121-176.

Dickey, Stephen M. 2000. Parameters of Slavic aspect. A cognitive approach. Stanford: CSLI Publications.

Hansen, Björn. 2004. The grammaticalization of the analytical imperatives in Russian, Polish and Serbian/Croatian. Die Welt der Slaven 49. 257-274.

Huson, D. H. \& D. Bryant. 2006. Application of Phylogenetic Networks in Evolutionary Studies. Mol. Biol. Evol. 23. 254-267.

Mauranen, Anna. 2008. Universal Tendencies in Translation. In G. Anderman \& M. Rogers (eds.), Incorporating Corpora. The Linguist and the Translator, 32-48. Clevedon.

Петрухина, Елена. 2000. Аспектуальные категории глагола в русском языке в сопоставлении с чешским, словацким, польским и болгарским языками. Москва.

Храковский, В.С \& А.П. Володин. 1986. Семантика и типология императива. Русский императив. Ленинград: Наука.

von Waldenfels, Ruprecht. 2006. Compiling a parallel corpus of Slavic languages. Text strategies, tools and the question of lemmatization in alignment. In B. Brehmer, V. Ždanova \& R. Zimny (eds.), Beiträge der Europäischen Slavistischen Linguistik (POLYSLAV) 9, 123-138. München.

Wiemer, Björn. 2008. Zur innerslavischen Variation bei der Aspektwahl und der Gewichtung ihrer Faktoren. In K. Gutschmidt, U. Jekutsch, S. Kempgen \& L. Udolph (eds.), Deutsche Beiträge zum 14. Internationalen Slavistenkongreß, Ohrid 2008 (Die Welt der Slaven. Sammelbände / Sborniki 30), 383-409. München: Sagner. 
SOURCES

ParaSol is developed as a joint project of the Slavic institutes of the Universities of Bern, Switzerland and Regensburg, Germany. Head of the project and the Bern team is Ruprecht von Waldenfels; head of the Regensburg team is Roland Meyer.

See parasol. unibe.ch and www.korpus . uni-r.de/ParaSol

\section{Corpus texts:}

Bulgarian (Л. Минкова): Михаил Булгаков, Майстора и Маргарита. Sofija, 1989. Belarusian (А. Жук): Міхаіл Булгакаў, Майстар і Маргарыта. Minsk, 1994.

Czech (A. Morávková): Michail Bulgakov, Mistr a Markétka. Praha, 1980. Croatian (A.V. Flaker): Mihail Bulgakov, Majstor i Margarita. Zagreb, 1993. Macedonian (Т. Угрошевиќ): Михаил Булгаков, Мајсторот и Маргарита. Skopje, 2006.

Polish (I.Lewandowska, W. Dąbrowski): Michaił Bułhakow, Mistrz i Małgorzata. Warsaw, 1969.

Polish (A. Drawicz): Michaił Bułhakow, Mistrz i Małgorzata. Wrocław, 1995.

Russian: Михаил Булгаков, Мастер и Маргарита. 1938.

Slovak (M. Takáčová): Michail Bulgakov, Majster a Margaréta. Bratislava, 2002

Slovene (J. Gradišnik): Mihail Bulgakov, Mojster in Margareta. Ljubljana, 1987.

Serbian (M. Čopić): Mihail Bulgakov, Majstor i Margarita. Beograd 1985.

Serbian (Z. Kocić): Mihail Bulgakov, Majstor i Margarita. Beograd, 1998.

Ukrainian (М. Білорус): Михайло Булгаков, Майстер і Маргарита. Харків, 2006.

AUTHOR CONTACT INFORMATION

Ruprecht von Waldenfels

Institut für Slavische Sprachen und Literaturen

Universität Bern

Länggassstrasse 49, 3000 Bern 9

Switzerland

ruprecht.waldenfels@issl.unibe.ch 